\title{
ONCE AGAIN ON SOVIET STATEHOOD IN LITHUANIA IN 1918-1919
}

\author{
Česlovas Laurinavičius
}

ABSTRACT This article makes the claim that by initiating the formation of the so-called Soviet statehood in Lithuania and Belarus (Litbel) the government of Soviet Russia did not intend 'to set in motion the broad mass of Lithuania for the revolutionary struggle' and tried to avoid social and national conflicts. However, the attitude of the Soviet government towards Lithuania underwent a change in the middle of 1919 when the advance of the Red Army to the West was halted.

Historiographical Tendencies since the Sąūdis Movement In Lithuania much has been written and discussed on the issue of statehood since the time of Sajūdis, the time of national rebirth in 1988-1989. The then discussion was characterized by a sort of rivalry between the two statehoods, national and Soviet, which had existed nearly side by side in 1918-1919. Doubtless, the national argument put forward during Sajūdis has turned out to be more persuasive. It was generally agreed that it was national statehood that was real and representing the self-determination of the Lithuanian nation. Meanwhile Soviet statehood was branded as advertising hoardings necessary for the spread of the world revolution into Germany or Poland. The most important argument for such identification was the fact that the concrete creators of Soviet statehood - Lithuanian Communists - refused categorically to recognize the right of nations for self-determination and did nor seek to separate Lithuania from Russia. Besides, Lithuanian Communists were criticized for having made some other serious mistakes tipping the balance in favour of national statehood. The most disastrous of those mistakes were the underestimation of national aspirations and rejection to parcel out land to Lithuanian farmers. ${ }^{1}$

${ }^{1}$ Naujas požiūris i Lietuvos istorija, ed. A. Eidintas and G. Rudis (Kaunas, 1991). Cf. the articles by L. Truska, Č. Laurinavičius, and A. Eidintas. 
After the re-establishment of Lithuania's independence discussions about Soviet statehood were forgotten and historians continued the study of national statehood. In this research there were considerable changes. Acknowledging in principle the importance and significance of this statehood, the scholars made a number of substantial criticisms. It turned out that the independent state of Lithuania in the period between 1918 and 1940 was not as independent as many would idealize it, that it faced serious problems in the realization of its right of self-determination, etc. ${ }^{2}$

In this context it seems that the arguments related to Soviet statehood in 1918-1919 could be developed and corrected. The point is that from the historical point of view both Lithuanian national statehood and Soviet statehood were two aspects of the same problem, that is, an extremely complex and intricate problem of Lithuania becoming a state in 1918-1919.

On the Motives of Forming Litbel One of the motives prompting the return to the issue of Soviet statehood would be the change of the initial statehood model of the Lithuanian Soviet Republic (LSR) into the Lithuanian-Belarusian Soviet Republic, the so-called Litbel. In the discussion of the Sajūdis period, the opinion that the formation of Litbel was inspired by the failed Spartacus Revolt in Berlin in early January 1919 was prevalent. It was a signal for the Soviet leadership in Moscow that the further promotion of world revolution towards Germany became complicated and consequently the Polish direction turned out to be a determining factor. Therefore, in the middle of January 1919 the Politburo of the Central Committee of the All-Union Communist (Bolshevik) Party adopted a decision to transform the LSR as a pro-German formation of the Lithuanian Council into Litbel, a kind of a Lithuanian-Belarusian structure, reflecting the projects of Polish federalism. ${ }^{3}$

${ }^{2}$ Cf. Z. Butkus, 'Jei opozicija gauna paramą iš svetur...', Kultūros barai, 1995 no. 8/9, pp. 80-84; L.Truska, Antanas Smetona ir jo laikai (Vilnius, 1996); Č. Laurinavičius, Politika ir diplomatija. Lietuviu tautinès valstybès tapsmo ir raidos fragmentai (Kaunas, 1997); A. Kasparavičius, Didysis X Lietuvos užsienio politikoje. 1926 metu Lietuvos ir Sovietu Sajungos nepuolimo sutarties sudarymo analize (Vilnius, 1996).

${ }^{3}$ A. Deruga, 'Leninowska polityka zagraniczna a geneza Litewsko-Białoruskiej Republiki Radzieckiej’, Z dziejow stosunków polsko radzieckich, 7 (1970), pp. 157-184; Č. Laurinavičius, 'Dèl tarybinio valstybingumo Lietuvoje 1918-1919', Literatūra ir menas, 29 October, 5 November 1988. 
Incidentally, in the Party discussion of early January the geopolitical motive of the formation of Litbel was not indicated by name (at least the author of this article failed to find such references), and merely general indications to 'the danger of Polish imperialism' were used. ${ }^{4}$ Therefore, the existence of such a motive in the minds of the Bolshevik leaders could only be presumed. Giving prominence to this motive suited very well the discourse of the Sajūdis period since it showed how at that time the Communist camp disregarded the potential political statehood of the Lithuanian nation and how Moscow leaders dictatorially carved the political map of Lithuania according to their geopolitical aims.

The presumption that the formation of Litbel was conditioned by geopolitical aims taking into account the situation in Germany and Poland is well founded. This supposition, however, requires some elaboration. It is also worth paying attention to those arguments that were mentioned in the 1919 Communist narrative in connection with the formation of Litbel (but passed over in silence by historians in 1988-1989). The Communist leadership maintained that 'Lithuania and Belarus are very close with respect to their demographic and economic composition' and that the formation of separate Lithuanian and Belarusian Soviet republics only "provokes nationalistic quarrels between local Communists concerning the subordination of a particular territory'.

Thus, on his arrival in Minsk in January 1919 the member of the Central Committee of the Russian Communist (Bolshevik) Party Adolf Iofe stated that 'there are territorial disputes between the Belarusian and Lithuanian Soviet republics over Zarasai, Vilnius and Grodno, and there are also disputes between the Belarusian Soviet Republic and Poland'. In Iofe's opinion, these quarrels could be 'a casus belli'. 5 Another representative of the Central Committee, Iakov Sverdlov, (at that time he could be ranked formally second in the Soviet leadership) came to Minsk on 2 February 1919 to take part in the session of the Central Committee of the Belarusian Communist Party. The presence of such a high-ranking Moscow representative was necessary because the leaders of the Belarusian Communist Party were opposed to the idea of the republic's reorganization into Litbel. Sverdlov labelled all motives for the formation of Litbel as 'a struggle against chauvinism

${ }^{4}$ Z. Angarietis, 'Lietuvos nepriklausomybė ir susivienijimas su Baltarusija', Komunistas, no. 25 (1919), Deruga, 'Leninowska polityka', pp. 170, 171, 175.

${ }^{5}$ Ibid, pp. 173, 178. 
and nationalism' and the endeavour for 'greater international unity'. 'All of us are members of the same party, and we must all abide by its decisions', 6 Sverdlov stressed. Thus, such motives would show that the formation of Litbel was an attempt to avoid nationalism manifesting itself even among the Communists.

\section{Liberalism of the Bolshevik Government in Lithuania in 1918-}

1919 The stance of the Bolshevik leadership to avoid nationalistic conflicts in Lithuania could be one of the reasons having stimulated Lithuanian left-wing intellectuals to cooperate with the so-called Kapsukas government. A complicated ethno-cultural situation at the boundaries between Lithuania and Belarus and the ensuing threats are separate topics. Suffice it is to say here that the enlightened circles of this region had been concerned with nationalistic threats since the late nineteenth century. Thus, it is small wonder that one of the ways to keep away from nationalism was an orientation to generally unsophisticated social-democratic movements, usually indifferent to national issues; in extreme cases even movements of the Bolshevik type seemed acceptable.

For example, the Lithuanian intellectual Vaclovas Biržiška, although not a Communist, agreed to serve as minister of education in Kapsukas' government. In one of his articles he presented his deliberations and defined the principles according to which Soviet institutions should function:

The words 'national' and 'ethnic' are always related to the notion of chauvinism and national hatred. The national struggle between the Poles, Jews, Belarusians and Lithuanians would be endless but for the workers' power. The workers concentrate their efforts on the maintenance of their power and they are not interested in the national struggles... < . > Local languages should be used in all offices. Assimilation, which in our case equals Russification, will never be the slogan of the workers' power. Equality of all languages ... Obligatory study of all local languages will be imposed by the Commissariat of Education. $<\ldots>$ It is necessary to alienate the working people from the vortex of the national struggle and to concentrate all efforts on the international solidarity of the workers, on socialism ....

From the traditional Bolshevik viewpoint such deliberations most probably would be treated as 'petty bourgeois'; nevertheless they

${ }^{6}$ Ibid.

${ }^{7}$ V. B. [Vaclovas Biržiška], 'Tautinis tyrimas', Komunistas, no. 22 (1919); V. B-ka [Vaclovas Biržiška], 'Darbininkų valdžia ir uždaviniai kultūros srityje', Švietimo reikalai, no. 1 (1919). 
were published in Komunistas. That makes one only wonder about the contemporary tolerance of the editorial board of the journal.

In addition to Biržiška, in Kapsukas' government Vladas Požèla was commissar of government affairs, and Vaclovas Bielskis commissar of agriculture. Besides, a great number of Lithuanian intellectuals, not belonging to the Communist Party, cooperated in Kapsukas' government in one way or another. They were Balys Sruoga, Kazys Binkis, Juozas Tumas-Vaižgantas, Jonas Basanavičius, Petras Mašiotas, Edvardas Volteris, Adomas Varnas, Konstantinas Jablonskis, Tadas Ivanauskas, Tadas Vrublevskis, Konstantinas Galkauskas, Juozas Talat-Kelpša, Konstantinas Glinskis, Aldona Didžiulytė-Kazanavičienè, Stasys Matjošaitis-Esmaitis, Antanas Purènas, Juozas Vaičkus, Petras Rimša, Jonas Vabalas-Gudaitis, Mečislovas Vasiliauskas, Augustinas Janulaitis, Juozas Zikaras, Zigmas Žemaitis, Juozas Žiugžda, and others. Incidentally, this cooperation lasted through the periods of both the Lithuanian Soviet Republic and of Litbel. Contrary to some statements, neither Biržiška nor Požèla nor Bielskis left Kapsukas' government after the formation of Litbel. 'No other government turned out to be so unsparing, so open-handed for cultural matters, education, science, arts...', Tumas-Vaižgantas afterwards estimated the activity of Kapsukas' government. This government had nothing to do with repressions; it was possibly the only one of such a kind in the entire Western region. Therefore, it can justly be said that Lithuanian enlightened society was more or less satisfied not only with the national or cultural policy but with the policy of Litbel in its entirety. How could the liberalism of Communist rule in Lithuania in 1918-1919 be accounted for, taking into consideration that liberalism, overall, was alien to this sort of power?

\section{On the Policy of the Bolshevik Leadership with Respect to Lithu-} ania in 1918-1919 Let us discuss in greater detail the problem of the so-called Soviet statehood in Lithuania, about its contemporary aims and means to achieve them by investigating this problem in three respects - national policy, agrarian policy and the technique of assuming power.

National Policy Concerning the realization of self-determination at the end of 1918 and the beginning of 1919 the following version is known: it was only on Lenin's and Stalin's instructions that the Lithuanian Communists (Vincas Mickevičius-Kapsukas, Juozas Alek- 
sa-Angarietis, Kazimieras Cichovskis, Semionas Dimanšteinas and others) formed the so-called Provisional Revolutionary Government and declared Soviet power 'as if independently from Russia'. And that was done ignoring the fact that those directions of Lenin and Stalin were incomprehensible to Lithuanian Communists because neither Kapsukas nor his comrades-in-arms imagined an independent Lithuania and considered Lithuania's right to self-determination unnecessary and even harmful. In this context Lenin and Stalin look like politicians caring about the self-determination of the Lithuanians. Meanwhile Lithuanian Communists look almost like fools, the more so that subsequently they themselves will repent in their writings of having made mistakes in the national question, of failing to perceive the significance of the right of self-determination, etc.

However, let us examine how the Bolshevik leadership adapted the right of self-determination for Lithuania. The commissar for national affairs Iosif Dzhugashvili - Stalin is said to have edited the manifesto of 16 December 1918 drafted by Lithuanian Communists. He allegedly gave emphasis to the Lithuanian Soviet Republic as a state by his corrections. However, the collation of the original and the published variants of the manifesto shows that Stalin merely deleted those places which unduly overstated Lithuania's attachment to the Russian Soviet Federal Socialist Republic. Stalin's corrections eliminated references to the right of self-determination and to explicit allusions to Lithuania as a state. Even hints of Lithuania's Soviet statehood were far from clear. ${ }^{8}$ (Incidentally, the available sources show that the published manifesto was not uniform: one of its variants contains the slogan 'Long Live the Liberated Lithuanian Republic of Workers and Peasants' and in another variant it is replaced by 'Long Live Lithuanian Workers' Soviets'; one variant declares the equality of all nations, and another bears no hint of the solution of the national question; and the threat 'to shoot on sight' the agents of the Council of Lithuania is substituted by the phrase "to punish by the severity of law'). ${ }^{9}$

On 22 December 1918 Izvestiia (Moscow) published the recognition of the independence of the Lithuanian Soviet Republic signed by the chairman of the Soviet of People's Commissars Vladimir

${ }^{8}$ Lietuvos TSR istorijos šaltiniai, vol. 3 (Vilnius, 1958), pp. 105-108.

${ }^{9}$ Komunistas, no. 3, 24 December 1918; G. Surgailis, 'Manifestas', Naujas požiūris ì Lietuvos istorija, pp. 37-41. 
Ulianov - Lenin. ${ }^{10}$ The following day the document was ratified. It is worth noting that the Soviet public discourse clearly avoided such phrases as 'the Lithuanian Soviet Republic', 'Soviet statehood', or just 'the right of self-determination of Soviet Lithuania'; in Lithuania proper similar phrases were not used altogether. Thus, this situation raises doubts whether Lenin and other Bolshevik leaders were really inclined to recognize Lithuania's right for self-determination (at least in the Soviet style) and only local Communists failed to evaluate the significance of that recognition. As noted above, the activity of Kapsukas' government in general, and in particular its attempts to conduct foreign policy (the notes to Poland, Germany and the Allied powers) show that the Bolshevik leaders in Moscow were interested in the Lithuanian Soviet Republic or Litbel as a buffer against foreign countries. ${ }^{11}$ And that would lead to a conclusion that the Leninist declaration of the recognition of Soviet Lithuania was meant for foreign consumption rather than for the benefit of Lithuania's population.

Agricultural Policy It is common knowledge that this policy is closely related to national self-determination. Here again, as in the case of the national question, according to an entrenched belief, the Lithuanian Communists did not understand the significance of the agrarian question, they did not parcel out land (as it was done in Russia) and that was a grave mistake affecting the fate of the whole Soviet statehood in Lithuania. Subsequently Kapsukas wrote: '... It was necessary to call the masses of workers and peasants to clean the estates, to divide land among workers and peasants, ... That would have set the broad mass of peasantry in motion and would have stirred the people to a much wider revolutionary movement'. ${ }^{12}$

It seems that under Soviet rule in 1918-1919 'the masses had not been set in motion'. If it was a mistake, was it the fault only of the Lithuanian Communists? According to documents, prior to the arrival of the Red Army to Lithuania there were a number of conferences with the participation of Lenin and other leaders of the

${ }^{10}$ Leninas ir Lietuva. Dokumentu rinkinys (Vilnius, 1969), pp. 64-65.

${ }^{11}$ K. Navickas, 'LTSR vyriausybès užsienio politika 1918-1919', LKP istorijos klausimai, no. 1 (1959), pp. 5-15.

12 The 8 June 1919 conference of the Litbel members on agrarian issues. LYA, f. 77 , ap. 2 , b. 13 , fo. 8 . 
Bolshevik Party on the future policy in Lithuania. However, none of the leaders indicated the need of parcelling out land in Lithuania (at least it was impossible to find such requests as in the case of proclaiming the Lithuanian Soviet Republic). Editing the manifesto of December 16, Stalin saw no need to include a statement about the union between the workers and peasants, which might be treated as an expression of a favourable attitude towards the peasantry. On the contrary, Stalin did not eliminate those paragraphs, which referred to the peasants as exploiters. In June 1919, when the Communists had been driven from Vilnius, Lenin himself participating at the conference of the Litbel Communists did not criticize their policy. Even such a sentence was recorded: 'Lenin endorsed our policy in the countryside'. ${ }^{13}$ Thus, it could be concluded that Lenin himself and other leaders of the All-Union Communist (Bolshevik) Party saw no need 'to set in motion the wide mass of Lithuania for the revolutionary struggle' between 1918 and 1919 .

The Question of an Armed Uprising It is common knowledge that the Bolsheviks treated the armed uprising as a classical way of seizing power, in particular at the initial stage of the history of Bolshevism. In the autumn of 1918 the phraseology of Lithuanian Communists abounded in expressions related to the preparation for ' $\mathrm{a}$ decisive struggle' or 'the last battle'. The December manifesto even contained a call 'Raise the flag of the revolt, everyone ... to arms!' However, the majority of the Communist documents show that there was no firm decision about an armed uprising in Lithuania. On the contrary, armed bands, raging at that time in the country (referred to as 'forest brothers' in the Communist vocabulary), were treated very negatively as 'centres of anarchy' rather than allies in the imminent armed uprising. ${ }^{14}$ Later Kapsukas admitted to making a mistake and regretted having not paid proper attention to the armed uprising and pinning his hopes on the arrival of the Red Army. ${ }^{15}$

The instructions of the leaders of the All-Union Communist (Bolshevik) Party did not contain any clear instructions on the organization of an armed uprising. At that time it was evident that

${ }^{13}$ Ibid., fos. 1-17.

${ }^{14}$ V. Kapsukas-Mickevičius, Pirmoji Lietuvos proletarine revoliucija ir sovietu valdžia (Chicago, 1934), pp. 98, 126-129.

${ }^{15}$ Kapsukas, Pirmoji Lietuvos proletarinè revoliucija ir tarybu valdžia (Vilnius, 1958), pp. 107-110. 
the Bolshevik leadership was interested in as peaceful a German retreat as possible and in its wake, as cautious an advance of the Red Army as possible. There are even sources indicating that at the start of the revolution in Germany in November 1918 Moscow offered the new Social-Democrat government in Berlin to form a 'defensive-offensive' alliance. Although Berlin rejected the proposal, there developed a rather favourable modus vivendi between the German troops retreating westwards and the Red Army following them. ${ }^{16}$ In any case, the aim of the Red Army was a revolutionary Germany. However, on the way to it a 'wall of nationalism', that is, the developing national states between the German and Russian empires had to be overcome. Late in 1918 Trotsky wrote that the Baltic region should not become a 'Chinese wall', but a bridge to a world revolution in the West. Lenin also indicated that it was very important to create 'a 'favourable atmosphere' for the movement of the Red Army towards Germany. ${ }^{17}$

At this juncture, it is worth noting that the first government of the Council of Lithuania (Taryba), headed by Augustinas Voldemaras, also adhered to the policy of 'non-setting in motion', of national consolidation and of the refusal to form armed forces. Voldemaras seems to have been influenced by the German stance. Besides, there were fears that the creation of Lithuanian armed forces would instigate other countries, and first of all the Poles, to do the same. Consequently, Lithuanian chances of staying in Vilnius would be minimized. Incidentally, the following events developed namely in this direction when Lithuanian officers dissatisfied by the government's passive approach to the armed forces allegedly 'revolted', and Sleževičius, having replaced Voldemaras, decided to call the nation to the armed struggle by proclamations, and the nation rose in arms, but that was not in Vilnius ... Thus, it could be presumed that between 1918 and 1919 there was an interesting concurrence of the attitudes of the governments of Voldemaras and Kapsukas, predisposed by the strategic viewpoints of Berlin and Moscow.

These observations could lead to the conclusion that late in 1918 and early in 1919 Lithuanian Communists did not make mistakes, more precisely, they did not deviate from the so-called Leninist course with regard to Lithuania. They seem to have followed Leninist

${ }^{16}$ Ia. Drabkin, Noiabr'skaia revoliutsia v Germanii (Moscow, 1967), p. 121.

${ }^{17}$ M. Kulichenko, Borba KP za reshenie natsionalnogo voprosa v 1918-1920 godakh (Kharkov, 1963), pp. 32-54. 
instructions to establish Soviet power in Lithuania with minimal social and national convulsions. Possibly that is why Kapsukas' government, having started its activity in Vilnius, resorted not to mass arrests but to attempts to enlist as many bourgeois representatives in the work of the soviets. Why Lithuanian Communists later repented of their supposed mistakes is another matter altogether. Forestalling the events, it could be presumed that Kapsukas and his comrades-in-arms became scapegoats for the failure of the campaign of a world revolution.

Changes from Mid-1919 Half a year later the situation became entirely different. Since the second half of 1919, the Bolshevik leadership had adopted the so-called policy of the Baltic neutralization. Its reasons were not quite clear - maybe the changes in the Berlin policy or most probably the aftermath of the growing influence of the Allied powers. Moscow issued a clear thesis about the right of the Lithuanian nation for self-determination. In contrast to the previous years, since mid-1919 the leadership of the All-Union Communist (Bolshevik) Party adopted a course of 'setting in motion the broad mass'. Cases were evident when the Bolshevik diplomats urged Lithuanian representatives to fight against the Poles and not to come under Jewish or Belarusian influence. ${ }^{18}$ Decisions were taken on the issue of land 'to instigate the peasants to drive out landowners ... landowners can be killed, estates burned', and the organization of partisan attacks were treated as 'highly desirable'. ${ }^{19}$ It is noteworthy that the answer to the question whether to come up with the slogan 'The Communist Party rises to power in Lithuania' was negative. The reason was that it was 'pointless to take power in Lithuania because there was no common boundary ...' ${ }^{20}$

Concluding Remarks The observations presented in this paper lead to several presumptions concerning the tactics of the Bolshevik leadership with respect to Lithuania in 1918-1919 and early in 1920. After the abrogation of the Treaty of Brest-Litovsk and with the Red Army approaching Germany, Moscow did not engage in 'the revolutionizing of the masses' at the border with Germany, i.e.

18 Č. Laurinavičius, Lietuvos - Sovietu Rusijos taikos sutartis (Vilnius, 1992), p. 126.

${ }^{19}$ Minutes of the session of the Politburo of the Russian Communist (Bolshevik) Party of 8 March 1920, LYA, f. 77, ap. 3, b. 2, fos. 1-6.

${ }^{20}$ Ibid. 
in Lithuania. The formulas of the buffer states - the Lithuanian People's Republic or Litbel - were necessary for the formation of a certain favourable image abroad, primarily in Germany. Repression and any major social or economic invasions were not practiced in the occupied territory of Lithuania. This context may account for the fact that the primary concerns of Kapsukas' government were the spheres of education and culture. In any case, the liberalism of Kapsukas' government distinguished it from the Bolshevik governments in Finland, Estonia, Latvia, or Ukraine.

In the second half of 1919 the situation became different - the failure of 'the revolution export' to the West and the disappearance of a territorial contact with Lithuania made the leadership of the Russian Communist (Bolshevik) Party employ the tactics of 'revolutionizing the masses' in Lithuania.

More generalized study of these problems is complicated by the fact that in July 1920, when the Red Army could have occupied the whole of Lithuania easily without 'a revolution of the masses' and thus have come into contact with Germany, the Lithuanian Communists nevertheless were preparing an armed revolt. However, it is to be hoped that the observations presented in this article will reveal some new aspects of Soviet Russia's attitudes towards Lithuania in 1918-1919.

Author Details

Doctor of Humanities Česlovas Laurinavičius is head of the Department of the Twentieth-Century History of the Lithuanian Institute of History. His sphere of research is political history and diplomacy of Lithuania and the world. He is author of four monographs Lietuvos - Sovietu Rusijos taikos sutartis 1920 m. liepos 12 d. (1992); Politika ir diplomatija. Lietuviu tautinès valstybès tapsmo ir raidos fragmentai (1997); Baltijos valstybiu geopolitikos bruožai XX amžius (2005, in co-authorship with Egidijus Motieka and Nortautas Statkus); Lietuvos istorija. Vol 12, part 1. Sajūdis: nuo "persitvarkymo" iki Kovo 11-osios (2008, in co-authorship with Vladas Sirutavičius).

Address: Lithuanian Institute of History, Kražių 5, LT-01108 Vilnius, Lithuania

Email: laurinav@yahoo.com 


\title{
DAR KARTĄ APIE SOVIETINI VALSTYBINGUMĄ LIETUVOJE 1918-1919 M.
}

\author{
Santrauka
}

\section{ČESLOVAS LAURINAVIČIUS}

Straipsnyje bandoma patikslinti kai kuriuos istoriografijoje nusistovejusius teiginius, susijusius su 1918-1919 m. sandūroje Lietuvoje egzistavusiu vadinamuoju sovietiniu valstybingumu. Būtent teiginius, kad sovietinis valstybingumas buvęs kurtas Sovietų Rusijos vadovybès (Vladimiro Uljanovo-Lenino ir Josifo DžiugašviliStalino) nurodymu, o Lietuvos komunistai (Vincas Mickevičius-Kapsukas, Zigmas Aleksa-Angarietis) tam priešinęsi ir pridarę reikšmingų klaidų: neịvertinę tautų apsisprendimo teisès reikšmès, nedalinę žemès lietuvių valstiečiams.

Straipsnyje nagrinèta bolševikų politika Lietuvoje nacionaliniu, agrariniu ir ginkluoto sukilimo klausimu leistų konstatuoti, kad $1918 \mathrm{~m}$. pabaigoje $-1919 \mathrm{~m}$. pirmoje pusejje pati bolševikų vadovybe Maskvoje vengè minèti Lietuvos apsisprendimo teisę, taip pat nedavè nurodymų dalinti dvarų žemių ir griebtis ginkluoto sukilimo. Daroma prielaida, jog tuo metu bolševikų vadovybẻ buvo suinteresuota išlaikyti Lietuvoje kuo stabilesnę padèti nacionaliniu ir socialiniu požiūriu, kad Lietuva taptų patogesniu tiltu Raudonajai armijai pasiekti Vokietiją ir Lenkiją. Tokia bolševikų taktika tam tikra prasme lèmè sąlygiškai liberalų Kapsuko vyriausybės ivvesto režimo Lietuvoje pobūdi, paskatinusi bendradarbiauti su šia vyriausybe nemažą būrị lietuvių inteligentijos.

Nuo 1919 m. vidurio, kai Raudonajai armijai kelias į Vakarus buvo atkirstas, bolševikų vadovybė Lietuvos atžvilgiu perejo prie naujos taktikos: pradèjo propaguoti tautų apsisprendimo teisę, skatino valstiečius imtis prievartinių akcijų prieš dvarininkus, ragino „darbo mases” ruoštis ginkluotiems išpuoliams. Tos direktyvos praktiškai reiškė nacionalinių ir socialinių konfliktų kurstymą Lietuvoje. 